\title{
Refik Halit Karay'ın Yezidin Kızı Romanında Yezidilik, Yezidiler ve Bazı Tespitler
}

\author{
Some Findings About Yezidis, Yezidism in Refik Halit Karay's Novel Named Yezidin Kizi (Daughter of Yezidi)
}

\author{
Mehmet Yazic1 ${ }^{\mathrm{a}^{*}}$ \\ ${ }^{a}$ Dr. Öğr. Üyesi, Bingöl Üniversitesi, Fen Edebiyat Fakültesi, Sosyal Hizmet Bölümü, Bingöl/Türkiye. \\ ORCID: 0000-0002-0671-6769
}

\section{MAKALE BILLGISİ}

Makale Geçmişi:

Başvuru tarihi:29 Kasım 2018

Düzeltme tarihi: 08 Aralık 2018

Kabul tarihi: 31 Aralık 2018

\section{Anahtar Kelimeler:}

Refik Halit Karay

Yezidin Kızı Romanı

Yezidilik İnanc1

Yezidiler

\section{ARTICLE INFO}

\section{Article history:}

Received 29 November 2018

Received in revised form 08 December 2018

Accepted 31 December 2018

\section{Keywords:}

Refik Halit Karay

The Novel Yezidin Kızı (Daughter of Yezidi)

The Yezidism Belief

Yezidis

\section{ÖZ}

Refik Halit Karay, hikâye, roman, mizah, hiciv, tiyatro, deneme ve hatıra türlerinde eserler vermiş bir yazardır. Onun eserlerinden biri de Yezidin Kızı romanıdır. Yezidin Kızı romanının ilk baskısı 1938'de Halep'te, ikinci baskısı ise 1939'da İstanbul'da yapılmıştır. Eser, günümüzde de ilgiyle okunmaktadır. Yazarın, Suriye'de sürgündeyken yazdığı Yezidin Kızı romanında, Yezidiler ve Yezidilik hakkında ilgi çekici bilgi ve tespitlere yer verilmektedir. Bu bilgi ve tespitler, bir asra yakın bir zaman önce, alanda yapılan gözlem, görüşme ve araştırmalar sonucunda elde edildiği için önemlidir. Bu çalışmanın amacı, Yezidin Kızı romanında yer alan Yezidilik ve Yezidilerle ilgili bilgi ve tespitleri roman okurlarıyla edebiyat araştırmacılarından sonra sosyal bilimcilerin de dikkatine sunmaktır.

\section{A B S T R A C T}

Refik Halit Karay has put forward works in different fields such as; story, novel, humour, irony, theatre, essay and remembrance. One of his works is the novel named Yezidin Kizı (Daughter of Yezidi). The novel printed first in 1938 in Aleppo, the second edition was printed in 1939 in İstanbul. It is read in our day curiously. In the novel which the author wrote in Syria while he was in the exile, there are interesting informations about Yezidis and Yezidism. Those informations are important since they were collected one century ago through observations, interviews and researches in the field. The aim of this study is to bring the information about Yezidis and Yezidism in the book to the attention of social scientists after readers and literature researchers.

\section{Giris}

Aktörün ${ }^{1}$ eylemleri ile sosyal çevresi arasında güçlü bir ilişki vardır. Çevrenin ilk çemberi olan aile, aktörün "Zihinsel haritasının oluşumuna öncülük eder" (Baran, 2013: 8). Bunu, daha sonra başta okul, arkadaş ve iş çevresi olmak üzere iç içe geçen sosyal çevrenin diğer halkaları tamamlar. Böylece her aktör, yapıp ettiklerini belirleyen bir yaşam biçimi kazanmış olur. Aslında, "Yaşam biçimleri 'habitus' dediğimiz bir

\footnotetext{
1 "Antropolojide ve sosyolojide, eylemde bulunan kişiden çoğu zaman bir aktör (ya da fail ) olarak söz edilir. Bu terim aynı zamanda
}

varoluş biçimiyle, zihin kalıplarıyla, gövde dilimizle ilintilidir. Kökleri derinlerde, geçmiş tarihe uzanan, tortusu bugünde, farkında olmadan üstümüzde, kişilerin davranışlarında ortaya çıkan bir kültürel hazineye işaret eder. Çocukluktan itibaren eğitime ve pratiğe dayanarak disipline ettiğimiz nefsimiz, gövde dilimiz, birbirimizle selamlaşma biçimlerimiz, yeme içme adetlerimiz, kültürel referanslarımız habitusumuzun bir parçasıdır, gündelik yaşam içinde ögrenerek aşinalık kazandığımız, otomatiğe bağladığımız bir

kolektif aktörleri de içerir ve bu nedenle 'şahıs', 'birey' gibi kelimelerden daha kapsamlıdır” (Eriksen, 2009: 74). 
kültürel hazine işlevi görür" (Göle, 2013). Ancak, bütünüyle çevremizin bize sunduğu bir varoluş biçimi olan habitusumuzun yani yaşam biçimimizin bir ürünü de değiliz. Deneyimlerimiz, gözlemlerimiz ve bilgilerimizle habitusumuzu her eylemimizle yeniden "üretiriz". Bu şekilde her an yeniden "yapılaşan" (Giddens ve Sutton, 2014: 55) toplumsal yapılar, sürekli değişir ve farklılaşır.

Bir toplumsal yapıda karşılaştığımız eylemler, kültürel referanslarımızla örtüşmediği oranda ilgimizi çeker; merakımız, hayretimiz ve şaşkınlığımız artar, daha dikkatli gözlemciler oluruz. Hatıra niteliğindeki eserlerden, kültürel referanslar ile gözlem yapan aktörlerin eylemleri arasındaki çelişkilerin; yazarlar için çok daha önemli, öğretici ve yazarların eserlerini etkileyen önemli faktörlerden biri olduğunu öğreniyoruz. Yazarlar, bu çelişkiyi en güçlü şekilde sürgün dönemlerinde yaşarlar. Kültürel referanslarından uzak diyarlara sürgün edilmiş yazarların, buralarda iyi birer gözlemci oldukları, bu yazarların günümüzde klasikleşen eserlerinde kullandıkları gözlemlerden anlaşılmaktadır.

Yazar, eserini oluştururken yazarlık yeteneğinden, habitusundan (kültür hazinesinden), deneyimlerinden ve gözlemlerinden yararlanır. Bundan dolayı, "Edebi eser, hiç şüphesiz onu vücuda getiren yazarın hayatı ile tarih ve sosyal çevresiyle de yakından ilgilidir. ... Çeşitli kaynaklardan gelen malzemeyi, sanatçı, yaratış süreci içinde, o anın da şuur ve şuur-altı kuvvetlerinin tesiri altında kalarak birleştirir" (Kaplan, 1997: 8). Bu sürecin sonucunda ortaya çıkan eser, belli bir usule ve düşünceye göre okunduğunda bize yazarının ait olduğu devrin ve düşüncenin yani yazarın habitusunun “anahtarını" verir (Kaplan, 1985: 8-9).

Bir edebi eser türü olarak romanda, yaşam koşulları ve olaylar ayrıntılı bir şekilde anlatıldığından Clara Reeve'nin de belirttiği gibi: "Roman gerçek yaşamın ve görgünün, ayrıca yazıldığı zamanın bir resmidir" (Ahmedzade, 2004: 50). O halde roman; yazarın gözlemleri ve deneyimleriyle zenginleştirdiği, yapılaşmasına katkıda bulunduğu habitusuna ve romanın yazıldığı dönem hakkında önemli verilere ulaşmamızı sağlayan kaynaklarından biridir.

Her roman yazarı, farklı düzeylerde de olsa romanlarında yaşadığı dönemin resmini sunmaktadır. Ancak bu sunumda bazı yazarlar çağdaşlarından daha başarılıdır. Örneğin, kendini "Realist bir muharririm" (Erdal, 1955'ten aktaran Aktaş, 2014: 43-44) diye tanımlayan Refik Halit Karay, çağdaşları arasında kültürel mirasını; deneyimleri, gözlemleri ve öğrendikleri ile ilişkilendirip kendine özgü bir üslupla sunmada başarılı olmuş romancılardan biridir. Her romanında yaşadığı dönemin farklı bir resmini sunan Karay, Yezidin Klzl romanında, eserin yazıldığı dönemdeki Yezidi topluluğu ve Yezidi inancının ayrıntılı ve ilgi çekici bir resmini vermektedir.

Konuyla ilgili literatür incelendiğinde Refik Halit Karay’ın, Yezidin Kızı isimli romanında Yezidilik ve Yezidiler hakkında verdiği ilgi çekici bilgilerle, edebiyat araştırmacılarının dikkatini çektiği görülmektedir. Türk Edebiyatı Tarihi (Kabakl1, 1966), Türk Edebiyatında Hikâye ve Roman (Kudret, 1965; Necatigil, 1989), Karatay'ın Biyografyası (Ebcioğlu, 1943; Aktaş, 2014) gibi çalışmalarda Yezidin Kızı romanına değinilmiş ve bu romanla ilgili bazı tespitler dile getirilmiştir. Kabaklı (1966: 344)'nın, Karay “Yezidin Kızı'nda, Yezidilerin inanç ve âyinlerine dair hayret verici sayfalar yazmıştır" ifadesi bu örneklerden biridir.
Mehmet Bayraktar (2012) ise, "Yezidin Kızı ve Êzîdîler" isimli makalesinde, yazarın hayatı ile roman hakkında kısa bir bilgi ve romanın özetini verdikten sonra, "Romanın Diliyle Êzîdîler ve Êzîdîlik" alt başlığı altında romandan seçtiği bazı paragraflar sunmaktadır. Bayraktar, bu makalenin yazılmasını da teşvik eden etkenlerden biri olan yazısını, araştırmacıların konuya ilgi duymasını sağlayacak şu cümlelerle bitirmektedir: "Refik Halid Karay, Yezidin Kızı romanında, sadece Êzîdî dininin esasları, töre ve törenleri konusunda bilgi vermekle yetinmez; Êzîdî etnografyası ve folkloru konusunda da bize ilginç gözlemler sunar.

Üç gün üç gece devam eden çalgıll, danslı, şenlikli Êzîdî düğünleri gibi, Êzîdî cenaze törenleri de, ilginç gözlemlerle verilir. 'Ey insanoğlu! Topraktan gelmiştin, bugün toprağa dönüyorsun!' sözü, Êzîdîlerin yolculama erkânını anlatan anlamlı bir söylemdir. Öte yandan Êzîdî beyleri, pirleri, kuçekleri, kavalları, müritleri ve fakirleri konusunda da ilginç bilgiler sunulur."

Sonuç olarak Refik Halit Karay'ın İstanbul'dan Suriye'ye sürgün edilmesi, Karay'ın hem kültürel hazinesinden uzaklaşmasına hem de kültürel referanslarıyla örtüşmeyen Yezidi topluluğuyla karşılaşmasına, bu karşılaşmada Yezidi topluluğu hakkında merak ve hayret içinde daha keskin gözlemler yapmasına ve Yezidin Klzı romanında dönemin Yezidi topluluğunun bir resmini vermesine vesile olmuştur. Yezidin Klzl romanında sunulan bu resimde; Yezidi topluluğunun tarihi, inançları, kültürleri ve yaşadıkları coğrafyayla ilgili dikkat çekici bilgi ve tespitler yer almaktadır.

$\mathrm{Bu}$ makalenin amacı, Karay'ın, Yezidiler ve Yezidilik inancıyla ilgili olarak derlediği ve Yezidin Kızı romanında, roman kurgusu içinde dağınık bir biçimde sunduğu verileri, roman okurlarından ve ilgili edebiyat araştırmacılarından sonra sosyal bilimcilerin de dikkatine sunmaktır. Makalede, romandan alınan verilerin içerik analizi ve değerlendirmesi yapılmamıştır. Çünkü kitapta, Yezidiler ve Yezidilikle ilgili hemen her konuya bir şekilde değinildiğinden bu makalenin sınırlarını aşacağı açık olan böyle bir çabaya şimdilik girişilmemiştir. Ancak bu yöndeki çalışmaların ileride yapılacağı ümit edilmektedir.

Çalışmada sunulan veriler, yazarın Yezidiler ve Yezidi topluluğunun inanciyla ilgili olarak verdiği bilgilerden ve bu inanç hakkında yaptığ 1 tespitlerden oluşmaktadır. Ancak dikkatli bir gözlemci de olsa yazarın kullandığı verilerin ve yaptığ 1 tespitlerin; bireysel gözlemlerinin, öğrendiklerinin ve deneyimlerinin sonuçları olduğu göz ardı edilmemelidir. Bununla birlikte bu sübjektif veriler ve tespitler, yaklaşık bir asır önce, doğrudan sahada yapılan gözlem ve görüşmelerin sonuçları olduğu için önemlidir. Yapılacak yeni çalışmalarla, sunulan bu verilerin ve yapılan tespitlerin doğruluğu, Yezidiler ve Yezidi inancı hakkında aynı dönemde sunulmuş benzer veriler ve yapılmış tespitlerle karşılaştırılarak sınanabilir. Çalışmanın bu nitelikteki araştırmalara öncülük edeceği beklentisiyle, romandan Yezidiler ve Yezidilikle ilgili ifade ve tespitler doğrudan alınmış ve alıntıların sayfa numaralarından da anlaşılacağı üzere bilgilerin kitaptaki veriliş sırasına bağlı kalınmıştır.

Bu çalışma; a) İŞİD'in, 2014 yılında Şengal bölgesine saldırısından sonra gündeme daha çok gelen Yezidiler ve Yezidilik inancıyla ilgili literatüre, yaklaşık bir asır önce sahada derlenmiş ve bir roman kurgusu içinde sunulmuş verileri ve yapılmış tespitleri sunarak katkıda bulunma; 
b)Romanda yer alan bu veriler, olgunun bugünkü durumuyla karşılaştırıldığında Yezidi topluluğunun ve Yezidilik inancının yaşadığı değişimi görme imkânı verme; c) Yezidiler ve Yezidilikle ilgili çalışmalara katkı sunma, d) Benzer çalışmalara dikkat çekme ve bu nitelikteki çalışmaları teşvik etme ihtimali olduğu için önemlidir.

Çalışmada, önce makalenin konusu olan romanın yazarı ve roman hakkında kısa bilgiler verilmektedir. Daha sonra, romanda Yezidiler ve Yezidilik hakkında olayların akışına göre serpiştirilmiş bilgiler ile yazarın Yezidiler ve Yezidilik inancıyla ilgili tespitleri verilmektedir. Makale, sonuç kısmı ve kaynakça ile sona ermektedir.

\section{Refik Halit Karay ve Yezidin Kızı Romanı}

Refik Halit Karay, 1888'de İstanbul'da doğdu. Yaşadığı iki ayrı sürgün döneminde İstanbul'dan uzak kaldı. Her iki sürgünden sonra da İstanbul'a döndü ve 1965 'te İstanbul'da öldü.

Refik Halit Karay, hayatını çoğunlukla gazeteci ve yazar olarak sürdürdü. Bir yazar olarak Fecri-Âti topluluğu içinde yer aldı. Aynı zamanda Fecri-Âti Encümen-i Edebisi Beyannamesi'ni imzalayan isimlerden biridir (Yücel, 1957: 47; Ebcioğlu, 1943: 25).

Refik Halit Karay’ın hayatının dönüm noktalarını yazarlık, eleştiri ve sürgünler belirlemiştir. Anadolu'nun farklı illerinde geçirdiği ilk sürgününün nedeni İttihat ve Terakki'yi eleştirmek için kaleme aldığı yazılardır. İttihat ve Terakki’ye muhalif yazılarından ötürü, birçok siyasiyle birlikte Sinop'a (1913) sürülmüş, oradan Çorum, Ankara ve Bilecik'e yollanmıştır. Ziya Gökalp'ın yardımıyla İstanbul'a dönmüştür (Kabakl1, 1966: 340).

İkinci sürgününün nedeni ise Milli Mücadele’ye karş1 İstanbul Hükümeti'nin yanında yer almak için yazdığı yazılardır. Anadolu'da başlayan Milli Mücadele'ye inanmayıp karşı çıkması ve sert yazılarla bu hareketi baltalamak istemesi, hayatının en acı dönemini hazırladı. İstanbul'un kurtuluşu ile Refik Halit 1922'de "Yüzellilikler" listesine alınarak yurt dışına çıkmaya mecbur edildi. On beş yıl kadar süren sürgün hayatını Beyrut, Halep ve Hatay'da gurbette geçirdi (19221938) (Bayraktar, 2012; Kabakl1, 1966: 340). Bu ikinci sürgünden, Cumhuriyet'in onuncu yılı dolayısıyla 1938'de çıkarılan Af Kanunu ile yurda döndü ve tekrar gazeteciliğe başladı (Bayraktar, 2012; Kabakl1, 1966: 340).

Refik Halit Karay’ın yaşadığı sürgünlerin, hayatına ve eserlerine etkisi büyüktür. Çünkü sürgünlük yalnızca coğrafi olarak yerinden edilme değildir. Bununla birlikte sürgünlüğün duygusal, politik, entelektüel sebepleri olduğu gibi edebi esere de etkisi vardır (Karabulut, 2018). Karay, hayata pozitif bakma alışkanlığına sahip olduğundan; hayatında ve eserlerinde sürgünlüğün olumsuz taraflarından çok olumlu etkileri ön plana çıkmıştır (Öksüz, 2017:277). Yazar, sürgünlerin doğurduğu olumlu sonuçları şöyle dile getirmektedir: "Her iki gurbetim de çok faydalı oldu. Birincisinde Anadolu'yu tanıdım. İkincisinde dünyayı tanıdım” (Baydar, 1960: :111).

Refik Halit Karay, yazarlığının başından beri realisttir ve toplumsal gerçekliklere duyarlı bir yazardır: "Gözlemlere dayanarak yurt gerçeklerine ve çeşitli insan katlarına yönelme yöntemini daha sürgüne gitmeden, Maupassant etkisiyle benimsemiş bulunan ve 1909-1910 yıllarında bu yolda birkaç da örnek veren yazar, Anadolu'da bu yöntemi uygulayacak elverişli bir ortam bulmuştur. Yakup Kadri Karaosmanoğlu'nun bir konuşmasında: 'O zaman Refik Halit ile ben, Maupassant'ın tesiri ile şehir içindeki tiplerden ayrılarak mevzularımızı köylerden, çobanlardan ve halkın arasından seçmeye başladık' ('Dikmen' gazetesi, 1942, say1 22) demesi bunu doğrulamaktadır. Böylece, o zamana değin yalnız türkülerde ve halk hikâyelerinde sözü edilen Anadolu insanı, Refik Halit' in Memleket Hikâyeleri ile ilk kez düzenli, sürekli ve bilinçli olarak aydın toplulukların edebiyatına girmiş; bu tutum, daha sonraki kuşakların eserleriyle bugüne değin sürmüştür. Yazar bir konuşmasında şöyle demiştir: 'Memleket Hikâyeleri çığır açmak bakımından bugünkü köy hikâyeciliğinin nüvesini teşkil eder. Ben Anadolu'yu bir köylü olarak değil, varlıklı bir şehir delikanlısı olarak gördüm ve anlattım" " (Kudret, 1965: 164)

Yazarlığa hikâye ile başlayan Karay'ın ilk eseri Memleket Hikâyeleri (İstanbul, 1919)'dir. Yezidin Kızı, yazarın Ístanbul'un Bir Yüzü (İstanbul, 1920) romanından sonra 1937'de Halep'te yayımladığ 1 ikinci romanıdır (Aktaş, 2014: 174).

Refik Halit Karay, eserleri ile deneyimleri, gözlemleri ve incelemeleri arasında doğrudan bir ilişki olduğunu, "Ben daha ziyade hayatta yaşadığım maceralardan ve bu hayat içinde gördüğüm tiplerden faydalanmış realist bir muharririm" (Erdal, 1955'den aktaran Aktaş, 2014: 43-44) ifadesiyle dile getirmektedir. Ebcioğlu (1943: 86) da "Kendi Yazıları ile Refik Halid" isimli çalışmasında "Refik Halid, kendi hayatını bazen endirekt olarak anlatmıştır. Meselâ 'Yezidin Kızı' Suriye çöllerinde yaptığı uzun gezintilerden aldığı intibaları, bir kül halinde gösterebilmek için icat ettiği bir mevzu ile çerçevelenmiş, yarı hayali bir romandır" tespitinde bulunmaktadır. Konuya ilgi duyan araştırmacılar da "Tamamen Halep'te yazılmış" (Ebcioğlu, 1943: 87) olan Yezidin Kızı romanı hakkında, "Refik Halid'in, hayatını dolaylı olarak anlattığ 1 romanlarından biridir” (Bayraktar, 2012) ve "Yazarın ikinci sürgün yıllarındaki gözlemi ve hatıralarını hareket noktası alan kurmaca bir eserdir" (Aktaş, 2014: 85) şeklinde değerlendirmelerde bulunmaktadırlar.

Bayraktar (2012)'ın Yezidin Kızı romanıyla ilgili bazı tespitleri şunlardır: Refik Halit Karay romanın başkahramanlarından (Hikmet Ali) biridir. Zaten roman, anılarla yoğrulmuş otobiyografik bir romandır. 1922-1938 yılları arasında devam eden Lübnan, Irak ve özellikle Suriye'deki sürgün yaşamında, bölgedeki birçok Kürt aydınıyla temasta bulunduğu gibi, çok sayıda etnik topluluk ve inanç topluluğunu da doğrudan tanıma imkânı bulmuştur. 1935'te Irak-Arap yönetimince Êzîdî Kürtlere yapılan katliam ve sürgün uygulamasının bu romanın yazılmasında etkili olduğu anlaşılmaktadır.

Yezidin Klzı romanının ilk baskısı 1938'de Halep'te, ikinci baskısı 1939'da İstanbul'da yapılmıştır. Yazar, Türkiye'ye döndükten sonra Tan gazetesinde yazı hayatını sürdürmüş ve Yezidin Kızı romanı 7.8.1938 tarihinden itibaren bu gazetede tefrika edilmiştir (Aktaş, 2014: 40).

Yezidin Kızı romanı; Yezidiler, Yezidilik ve Yezidi topluluğun yaşadığı çevre hakkında ilginç bilgiler verdiği gibi, eserin yayımlanma süreci ve eser yayımlandıktan sonra yaşanan gelişmeler de dönem hakkında bazı bilgilere ulaşmamızı sağlamaktadır. $\mathrm{Bu}$ da yazar ile eserin serüvenlerinin iç içe geçtiğini göstermektedir. Örneğin, sürgünün, aynı kaderi paylaşanları bazı konularda iş birliği yapmaya zorladığını (Bayraktar, 2012), Yüzelliliklerin Türkiye'de yayım 
yapmalarını yasaklayan bir kanunun olduğunu ve bundan dolayı Yezidin Kızı romanının ilk baskısının Türkiye'de değil Halep'te yapıldığını, o dönemde Halep'te Latin harfleriyle baskı yapan bir matbaanın olmadığını, yazarın kitabı basmak için İstanbul'dan Latin harfleri ile baskı yapan matbaayı getirttiğini ve ilk baskıyı eşinden yardım alarak gerçekleştirdiğini öğreniyoruz. Ayrıca ilk olarak 1000 adet basılan Yezidin Kızı romanının 25 nüshasının kalın kâğıt üzerine numaralı olarak tabedildiğini ve bunun " 1 " numarasının "Atatürk'e; yürek çarpıntılarıyla!" ithafı ile Atatürk'e gönderildiğini ve kitap gönderildikten bir süre sonra Yüzelliliklere af haberlerinin çıkmasında, Atatürk'e hediye edilen Yezidin Klzl romanının etkisinin de olduğunun ileri sürüldüğünden haberdar oluyoruz (Ebcioğlu, 1943: 87). Bunların yanı sıra edebiyat araştırmacılarının Yezidin Kızı romanındaki çöl tasvirlerini, Türk edebiyatının en güçlü parçaları arasında (Kabaklı, 1966: 346; Ebcioğlu, 1943: 87) değerlendirdiklerini de öğreniyoruz.

Bu çalışmada, Refik Halit Karay'ın Yezidin Kızı romanının İnkılâp Yayınlarından 2017'de basılan nüshası esas alınmıştır. Üç bölüm ve yirmi alt başlıktan oluşan roman 157 sayfadır. Bu ana başlıklar ve alt başlıklar şöyledir:

Birinci ana başlık Denizde'dir. Bu başlık altında şu 5 alt başlık yer almaktadır:

1. Kürtçe Konuşan Arjantinli Kız,

2. Doğan Güneşe Rükû Ediyor,

3. Güvertede Laso Kullanıyor,

4. Çölün Ortasında Randevu Veriyor,

5. Tüdmür'de Bekleyenin İsmi.

İkinci ana başlık Çölde'dir. Bu başlık, şu 7 alt başlıktan meydana gelmiştir:

1. Seraplar Arasında Zeliha'ya Doğru,

2. Yılbaşı Gecesi Bir Metampsikoz Bahsi,

3. Gökte Oturanın Dünya Yüzündeki Sülalesi,

4. Cehennemi Söndüren Gözyaş1,

5. Çöl Zebanilerinin Meclisinde,

6. Firat'ın Öte Yüzü,

7. Sahrada Başbaşa Kalan Bir Çift,

Üçüncü ana başlık Dağda'dır. Bu başlığın altında yer alan 8 alt başlık şunlardır:

1. Sincar Hisarı'nın Misafiri,

2. Bir At Gezintisinde,

3. Mukaddes Emanetler Önünde,

4. Hakikate Daha Çok Benzeyen Hayal,

5. Şeytana Yaranmaya Çalışanlar Arasında,

6. Batan Güneşin Kızıllığında Duyduğum Sözler,

7. Cehennemi Alevlendiren Gözyaşı

8. Şemun'un Görünen Gözleri.

\subsection{Birinci Bölüm}

Bölümün ana başlığı "Denizde"dir. Bu başlığın seçilmesinin nedeni, aynı zamanda romanın anlatıcısı da olan erkek karakterin (Bayraktar'a göre yazarın kendisidir) kadın karakterle vapurda karşılaşmalarıdır. "Suriye'de babadan kalma köyünü görmeye giden Hikmet Ali (romancının kendisi), Marsilya'da bindiği vapurda genç ve güzel bir kadınla karşılaşır ve ona ilk anda çarpılır” (Bayraktar, 2012).

$\mathrm{Bu}$ bölümde, romanın adından (Yezidin Klzı) hareketle vapurdaki kadın karakterin konuştuğu dil, yaptığı ibadet ve yemek tercihi daha doğrusu yemediklerinin listesi "gizemli" hale getirilerek okurun ilgisi çekilmektedir.

Hikmet Ali'nin “Dikkatini çeken ilk husus, bu kadının Kürtçe konuşmasıdır. Bu nedenle romancı, kitabının ilk bölümüne 'Kürtçe Konuşan Arjantinli Kız' başlığını koyar” (Bayraktar, 2012).

Vapurun komiseri, Kürtçe konuşmasıyla Hikmet Ali'nin dikkatini çeken kadını şöyle tanıtır: "Matmazel Zeli Della Yezdi, Arjantin'in Mendoza şehrinde 1910 senesinde doğmuş, arazi sahibi. Kendisini vapura kadar Arjantin'in Marsilya konsolosu getirdi. Çok, pek çok zengin olduğunu söylediler. Beyrut'a, oradan da çöldeki harabeleri gezerek Bağdat'a gideceğini işittim; mükemmel Fransızca bilir" (s. 10).

Zeli'nin bir sabah vapurda doğan güneşe karşı ibadet ettiğini gören Hikmet Ali'nin, onun hakkındaki şaşkınlığı da merakı da artar. "Birdenbire donakaldım, gözlerime inanamıorum: İspanyol kızı, doğan güneşe karşı dizlerini büktü, hürmetle, vecitle, üç kere eğildi ve bir türbeden çıkar gibi, hiçbir yere bakmadan geri geri, usulcacık yerine çekildi” (s. 20).

Yine vapur komiseri, Hikmet Ali'ye Zeli'nin yemek tercihiyle ilgili olarak da şu bilgileri vermektedir: "Dostumuz senyoritanın kendine göre orijinal halleri var. Mesela yemek listesindeki kati emirlerine şaşmamak mümkün değil. Balık, domuz eti, marul ve lahananın yüzünü bile görmek istemiyor. Vapura girdiği gün metrdotele bu isimler yazılı bir pusula verdi; büyük bir bahşişle beraber..." (s. 31).

Romanın vapurda tanışan kadın ve erkek kahramanları; vapurdan inmeden önce, çölde buluşmak için sözleşirler. Birinci bölüm biterken kahramanların buluşacakları yer ve niçin, nasıl buluşacaklarının bilinmemesi okurun ilgisini canlı tutan olaylara yenisini eklemektedir.

Zeli: "Mösyö Ali, köyünüzde bana emin olarak rahatça oturunuz. Bir aya kalmaz muhakkak haberimi alacaksınız!" (s. 36). "İşlerim, zaten sizi görmemi, sizinle görüşmemi icap ettirecek!” (s. 37). "Beni bir fleur du mal (Fransızca, kötülük çiçeği) yaptınız. Ciddi konuşalım: Yarın 1933 senesi ikinci teşrinin 29'uncu Salı günüdür. 1933'ün sonuncu Cumartesi günü çölde tayin edeceğim bir noktasında buluşacağız. Dün dediğim gibi, zamanı gelince benden haber alacaksınız. Kabul mü?"

Hikmet Ali: “Kabul!” (s. 39).

\section{2. İkinci Bölüm}

Hikmet Ali ile Zeli, bir önceki bölümün sonunda sözleştikleri gibi, bu bölümde çölde buluşuyorlar. Bundan dolayı bölümün ana başlığı "Çölde"dir. Bu bölümde; Yezidilik inancında tenasüh anlayışı, Yezidilerin akideleri hakkında yaygın ancak yanlış olan bilgiler, Yezidilerin yakın tarihinden kesitler, 
Yezidi itikadının temelleri, inancın kaynağı, Tanrı anlayışı, inancın ayırt edici özelliği ve inançlarıyla ilgili efsaneleri/söylenceleri, şarabın mubahlığı, erkek çocukların sünneti konularında bilgiler verilmektedir.

Tenasüh konusunda Hikmet Ali ile Zeliha arasında geçen bir diyalogda, Zeli'nin kim olduğunu, Yezidiler arasındaki konumunu ve bir projesinin olduğunu öğreniyoruz. Zeli, Yezidi inancında tenasüh anlayışıyla birlikte kendisini ve amacını şu cümlelerle dile getirmektedir: "Ruhlar bir canlı kalıptan diğerine geçerler, yaşayanda barınırlar ve mütemadiyen değişe değişe yaşarlar. Ruh muammasının en doğru hal şekli budur; ben metampsikoza iman edenlerdenim; benim dinimin temelini tenasüh (ruh göçü) teşkil eder; dinimin ve ilmimin esaslarını... Artık gizlemeye lüzum yok: Ben Yezid'in kızıyım!"' (s. 53).

“' 'Yani', dedim, 'Yezidisiniz, bu cemaate mensupsunuz?'

Evet, Yezidi'yim, fakat o cemaate adını veren büyük Yezid'in de kizı1ım!” (s. 53)

"Ve ben cemaatimi kurtarmaya memurum!" dedi (S. 53).

Zeli'nin Yezidi olduğu belirtildikten sonra, onun dilinden bir mezhep olarak tanımlanan (s. 54) Yezidiliğin akideleri hakkındaki yaygın ancak yanlış olduğu vurgulanan şu bilgiler verilmektedir. “... Ve pek fena, değil mi? Mesela Şeytan'1 Allah tanımak, tavus kuşuna tapmak, kadın erkek yüzlerce kişi bir arada 1şıkları söndürüp fuhşa dalmak ..."

"Bunlara benzer şeyler işitiriz."

"Hâlbuki biz de Müslümanlar, Hristiyanlar, Museviler gibi yerin ve gögün yaratıcısı bir rabbül'alemin tanırız” (s. 54).

Yezidilerin, temel geçim kaynağı olarak ziraat ve hayvancılığı tercih ettikleri belirtilmektedir. Bunun nedeni ise şöyle açıklanmaktadır: "Ziraat ve hayvan yetiştirmek Yezit kullarının esas işidir, zaten bunlar haricinde memnu kârlara başvurdukları için felaketlere uğradıklarına inananlar aramızda çoktu" (s.55).

Yezidilerin akideleri hakkında yanlış bilgiler ve bunların doğru biçimleri verildikten sonra, romanın yazıldığı döneme yakın bir tarihte Yezidilerin yaşadıkları katliamlar anlatılmaktadır. "1892 bizim için kan ve ateş yılıdır... Daha evvel de büyük felaketlere uğramıştık. On sekizinci asırda iki yüz elli bini aşan nüfusumuz Kürt ve Türk akınları önünde mütemadiyen eriyordu. 1638'de Melek Ahmed Paşa'nın Yezidi seferi, tarihte kızıl izini bırakmıştır. Osmanlı Devleti'ne karşı bir Kürt isyanı çıkaran Ravandızlı Mehmet de aynı ırktan olduğumuza bakmayarak Sincar'a yürüdü ve ahalisini zalimcesine ezdi. O zaman Babıâli, Yezidilerin tarafını tutmuş ve 1835 'te ordu yollayarak sergerdeyi başımızdan defetmişti. 1843 ve 1847 tarihlerinde de yine Kürt kıyımları olmuş, Nasturilerle beraber cemaatim tekrar Kürtlerin hücumuna uğramıştı. Size, kana boyanmış mazlum tarihimizi anlatmak istemiyorum; maksadım küçük milletimin daima kahır gördüğünü hatırlatmaktır. Biz fasılasız darbe yedik; buna son ve amansız darbeyi Ömer Paşa vurdu; Yezidileri ortadan büsbütün kaldırmak istemişti. Katliamların ne demek olduğunu size tasvir etmeyeceğim; pek korkunçlarını çok yakından görmüş olmanız lazım gelir. Ömer Paşa'nın kan ve pıhtı kokan çeteleri, o dediğim şeametli senede sayımızı elli bine indirdi. On beş binimiz, görünüşte Müslüman olduk; büyük bir kısmımız da Hristiyanlığa geçti” (s. 54-55).
Romanda, Yezidilerin yaşadıkları katliamlar verildikten sonra, tekrar Yezidilik inancına geçilmiş ve eski dinlerden biri olarak değerlendirilen Yezidi itikadının temelleri hakkında bir literatür değerlendirmesi yapılmıştır. "Yezidiler üzerine yazılmış olan eserlerde, mesela Bore, Guinet, Layard'ın, hatta Karmelit papazı Anastas, Şehristani ve Timur Paşa'nın etütlerinde lüzumsuz birçok tafsilat bulabilirsiniz; öyle tafsilat ki en eski dinlerden biri olan Yezidiliği, Havarici kavgalarına yaklaştırırlar; Yezid'i Muaviye'nin oğlu sandırırlar, Müslümanlığın ve Hristiyanlığın şeytanını bizim Tavus'muz, Allah'ımız mertebesine çıkarırlar. Hayır! Bunlar yanlıştır”' (s. 58).

Romanda, Zeli'nin ağzından Yezidilerin ırkı, yaşadıkları göç ve yerleştikleri coğrafyanın özellikleri hakkında ilginç tespitler dile getirilmektedir. "Biz Hazar Denizi'nin çark kıyılarında yaşamış bir ırktanız; belki bu ırkı şimdilik İranlı, Türk veya Kürt diye tayin edemeyiz. Muhakkak olan cihet, petrol kaynaklarının çocuklarıydık, onun için de ateşperesttik. İstila sarsıntılarıyla yerimizden koparak cenuba kaydık, fakat öyle bir yere geldik ki geçtiğimiz toprakların altından yine ateşin kılavuzluk ettiğine hükmedilebilirdi: Yerleştiğimiz yer tekrar bir petrol sahası oldu. Bakü'de fışkıran gaz, bugün insan eliyle konulmuş borulardan Batum'a akıyor, fakat toprağın içindeki damarlardan Musul tarafına, Kerkük'e sızıyor, Sincar Dağı'nı derinden aşarak..." (s.58).

Yezidilik inancının kaynağı hakkında ise şu bilgiler verilmektedir: "Yezidiliğin esasında güneşe taptıran eski İran dinini ve bunu 1slah eden Zerdüştlüğü, Zendavesta'y1 aramalıdır. İyi ve fena iki prensibin çarpışması: Ahuramazda ve Angramainiyo... Yani Farsçanın Hürmüz ve Ehrımen'i. Biz gönlümüzde bu akidelerle yola çıkmıştık, Hristiyanlık önümüzü kesti, sonra Müslümanlarla karşılaştık. Bu temaslar bir nevi fikir karışıklıkları ve kaynaşmalar yaptı; artık Zend'in Avesta'sı yerine elimizde bir Muşafiras vardır: Kara kitap denilen kitabımız. Üç dinin ve eski, yeni birçok mezhep ve tarikat itikatlarının birleşmesinden vücuda gelen bu kitap Zendce değildir, ilk yazıldığı dilde Arami harfleriyle de değildir, Farisi bozması bir Kürtçedir” (s. 58-59).

Yezidilikte özgün bir Tanrı ve teslis inancının olduğu belirtildikten sonra, Zeli'nin dilinden Zeli’nin; bu inanç sistemi içindeki yeri anlatılmaktadır. "Yezidi bir tanrıya inanır; fakat bunun altında bir ikinci tanrı daha vardır: Bu da bir teslistir. Katolikler, bilirsiniz ki Allah’ta üç şahsiyetin mevcudiyetine, bu üçün tek ve taksim edilmez bir birlikte, birbirlerine müsavi bir cevherden olduğuna itikat ederler. Bu üç şahsın üçü de, onlarca hakiki Allah'tır, ama yine de Allah birdir; Müslüman ve Musevi imanıyla uyuşmayan ancak Hintli ruhunu kavrayan bir itikat... Bizdeyse Allah ayrıdır, tektir; teslis onun yanında ikinci derecede bir mevkidedir.

$\mathrm{Bu}$ teslisi Tavus, Şeyh Hadi ve Yezid teşkil eder. Yezid, Tavus'un oğludur; bildiğimiz şekilde bir insandı. İsa gibi insanlar içinde yaşadı, Rab'bin kanunlarını tanıttı, nihayet Allah'ın yanına erişti ve teslisin iki uzvu arasında yer aldı" (s. 59).

\section{"Yezid dünya yüzünde bir oğul bırakmıştı.}

İşte ben bu ilahi ve mukaddes sülaleden gelen Prens Ali'nin ve aynı sülaleye mensup Prenses Ayşe'nin kızları olmam dolayısıyla Yezid'in de kızıyım... Yezid bende'dir, ben'im!" (s. 59). 
Yezidi inancında güneşin müstesna bir yeri vardır. Güneşin bu konumu: “... Güneş mabedindeyiz, biz doğan güneşe ibadet ederiz. Bu sabah ilk işim, tanyeri ağarmadan buraya gelmek oldu; doğan güneşe, kendi adına yapılan şu ulu ibadethanede rükûa vardım.” (s. 63) cümleleriyle dile getirilmektedir.

Yezidiliğin diğer bir özelliği de sır merkezli inançlardan biri olmasıdır. Bunun nedeni Zeli’nin ağzından, “Cemaatim kitap, niyaz ve ayinleri hakkında sir vermez; fakat bu, etraflarını çeviren mutaassıp ve mütecaviz düşman kitlelerinden korunmak için kurulmuş bir kaideydi" (s. 63-64) şeklinde açıklanmaktadır. Zeli, inançlarıyla ilgili sırrı Hikmet Ali'den gizlemeyeceğini, "Yirminci asrın laik ve ciddi bir münevverine açılmakta mahzur yoktur" (s. 64) gerekçesiyle açıklamaktadır.

Romanda, Zeli, Yezidilerin nüfusu ve bu nüfusla ilgili projesi hakkında şu bilgileri vermektedir: "Bugünkü politik coğrafya bakımından Irak, Suriye ve Türkiye arazisinde yerleşmiş bulunan cemaatimin Kafkasya'da Surhdar ve Hindistan'da Lebkos adını almış iki ufak şubesi vardır; yekûnumuz aşağı yukarı seksen bin kişiyi bulur. $\mathrm{Bu}$ halkı, evvela Sincar'dakilerden başlayarak bir yere toplamak ve onlara modern, emniyetli bir yurt kurmak... İşte, projemizin ana hatt1" (s. 64).

Yezidilik inancının ayıt edici özelliklerinden biri de şöyle dile getirilmektedir: "İyi ya... Yezidilik bütün zahiri alametlerden sıyrılmış tek dindir; bizim ne mabedimiz, ne minare, ne çan, ne haç, ne vaiz, hiçbir işaret ve ayinimiz yok. Adetlerimiz ise kimseyi incitecek mahiyette değildir... Mesela benim balık yemememden komşuma zarar gelir mi?" (s. 66-67).

Romanda, Yezidilerin balık yememelerini Zeli'nin dilinden anlatılan şu söylenceye dayandırdıklarını öğreniyoruz: "Dedem Yezid, doğduğu şehri bırakıp Allah'ın emir ve nehyini talim için başka memlekete giderken önüne bir deniz çıktı ve yolunu kesti; balıklar ayaklarının altında sımsıkı toplandılar ve ona sırtlarının üzerinden bir köprü kurarak öbür kıyıya geçmesini temin ettiler. Bu yardımdan dolayı balıkların kutsiyeti vardır" (s. 67).

Yazarın bu söylenceden yaptığı çıkarım ise şöyledir: "Musa'nın Kızıldeniz'i geçmesini hatırlatan bir rivayet... Hoş, dinler birbirlerine benzerler ve birine inanınca ötekilerin hikâye ve efsanelerine inanmamak için sebep kalmaz. Yunus'un balık sayesinde kurtulduğuna inandıkları halde balık yemekte zarar görmeyenlerle kıyas edilirse, Yezidilerin iyiliği unutmadıkları anlaşılıyor" (s. 67).

Zeli'nin dilinden, Yezidilerin konuştukları dil ve dilin önemi hakkında "Bizce lisanın ehemmiyeti yok... Zaten asıl dilimiz, zannediyorum, eski İran lehçelerinden biri, Persçe veya Pehleviceydi..." (s. 69) tespitleri dile getirilmektedir.

Bu bölümün sonlarına doğru, biri Nuh Tufanı diğeri tenasühle ilgili olmak üzere Yezidilerin iki söylencesine yer verilmektedir. Nuh Tufanı'yla ilgili hikâye şöyledir:

“ Dünyayı basan sular çekilir gibi olunca Nuh'un gemisi kayaya çarpıp tehlikeli bir yara aldı. Nuh sordu:

'Bu deliği kim kapatacak ?' Yılan ortaya atıldı:

'Ben', dedi, 'şu şartla ki benî Âdemi (Âdemoğulları, insanlar) elime teslim edeceksin, kanını emeceğim.' Nuh teklifi kabul etti, fakat delik kapanıp tehlike kalmayınca yılanı yakaladı, ateşte yaktı ve küllerini rüzgârın önüne serpti. Bu küllerden pireler peyda oldu ve insanların kanını, dünya durdukça usul susul, azar azar emmeye koyuldu" (s. 70).

Tenasübe (Birbirine uyma, yakışma.) dair efsane ise şöyledir:

"Bizim pir dediğimiz büyük şeyhlerimizden biri öldü ve gömüldü. Ruhu sığınacak bir yer arıyor, durgun bir gölün üzerinde şaşkın ve kararsız dolaşıyordu. O sırada kendi genç kızı su kenarına gitmişti; testisini doldurdu, birkaç yudum içerek hararetini bastırdı. Dokuz ay sonra bir oğlu dünyaya gelmişti. Bu çocuk o büyük pirin kendisiydi!” (s. 70).

Bu bölümde son olarak Yezidilik inancında şarap içmenin yeri ve vaftiz yapıp yapmadıkları üzerinde durulmaktadır.

Romanda, "Şarap mübah mıdır?" sorusu sorulmakta ve Zeli'nin dilinden şu cevap verilmektedir:

'Evet; hatta 'Eucharistie' yapan köylerimiz vardır. Mesela tek tük bazı köylerde halkımız, Hristiyanlar gibi bir masa etrafina toplanır; reis eline şarap dolu bir kupa alır, yukarıya kaldırır. Müritler sorarlar:

'Bu nedir?' cevap verir:

'Bu, İsa'nın kupasıdır. İsa onun içinde mevcuttur.' Kadehi ağzına götürür ve sonra, derin, hürmetli bir sükût içinde bekleyen cemaate bu kadehi, birer birer sunar. İsa bizim de en büyük peygamberlerimizdendir. Yalnız, onun çarmıha gerildiğine inanmayız. Çivilerden birisini İsa'ya inananlardan biri Yahudilerin elinden çalmıştır ve çarmıh cinayeti bundan dolayı yapılamamıştır" (s. 70-71).

Romanda, "Vaftiz yapar misınız?" sorusu Hikmet Ali tarafindan sorulmakta ve Zeli bu soruya şu cevabı vermektedir:

"Hem vaftiz hem de sünnet, ikisini de yaparlar. Yezid sünnetin hamisidir. Sünnet edilen çocuk veya sağdıcı ameliyata başlanırken: 'Ben nurlu Yezid'in kurbanıyım!' der. Teslise dâhil Şeyh Aadi de vaftizi himaye eder” (s. 71).

Hikmet Ali (yazar), Yezidilik kıssalarına (hikâyelerine, efsanelerine, söylencelerine) yukarıdaki örnekleri verdikten sonra beğendiği kıssaya da yer vermektedir. "Benim en beğendiğim kıssalardan biri de şudur: Memnu meyve vakasından sonra Allah, Âdem'i cennetten kovmakla kalmadı. Onu cezalandırmak için cehennemi kurdu. Fakat Âdem topraktan bir testi yaptı, içine gözyaşlarını biriktirdi ve dolunca ateşin üstüne döktü, ateş söndü, böylece kurtularak kendisini ve kendisinden sonra gelecek nesli müebbet azaptan kurtardı" (s. 71).

Romanın ana başlığg "Çölde" olan ikinci bölümü biterken "Anlaşılan artık Irak'tayım; Sincar Dağlarında, Yezidler ülkesindeyim” (s. 93) ifadesine yer verilmektedir.

\section{3. ÜÇüncü Bölüm}

$\mathrm{Bu}$ bölümde, ağırlıklı olarak Yezidilik inancının bazı sosyolojik uygulamalarına yer verilmektedir. Bir inanç topluluğu örneği olan Yezidilerin, romanın bu bölümünde yer verilen uygulamaları özgün ve ilgi çekicidir.

Bölümün ana başlığ̣ "Dağda"dır. Bu başlığın seçilmesinin nedeni romanın iki ana karakterinin (Hikmet Ali ile Zeli'nin/Zeliha'nın) Sincar Dağı'nda kurulu bir hisarda kalmaları ve zaman zaman at gezintisi yapmalarıdır. Bundan dolayı yazar, bu bölümdeki ilk iki alt başlığı "Sincar Hisarı'nın Misafiri” ve "Bir At Gezintisinde" olarak koymuştur. 
Zeliha'nın ağzından bu hisarın niçin seçildiği şu ifadelerle dile getirilmektedir: "Yezidi prenslerinin, eskiden Musul'a on saatlik yolda, Dahok kasabasına yakın bir yerde haşmetli sarayları vardı. Bunlar şimdi harap halde, hâlâ duruyor. Sincar'da kalacağım müddet içinde bu hisarı seçmemin sebebi biraz da ailemin tarihiyle ilişskili olmasıdır. Babam bu bina altında kanlı vakalar gördü ve buradan hicret etti. Ömer Paşa yine bu hisarda aylarca kaldı, binlerce kafa bu şatonun avlusuna yığıldı. Altı mukaddes Yezidi bayrağından dördü generalin eline geçmişti; iki tanesi kurtarılabildi ve biri bu binanın mahzeninde saklanıldı" (s. 101). Romanın Yezidi karakteri olan Zeliha'nın ağzından, Sincar'da kaldıkları hisarın niçin seçildiğiyle ilgili bu anlatımdan yazarın asıl amacının, Sincar ve çevresindeki Yezidilere ait bazı tarihi yapılara, bu yapıların Yezidi bireyler ve Yezidi topluluğunun bütünü için önemine ve bu yapılarda yakın tarihte yaşanmış “üzücü” olaylara dikkatleri çekmek olduğu anlaşılmaktadır.

Yezidi inancı müminlerinin, inancın önderlerine gösterdikleri ilgi ve ibadet maksadıyla sergiledikleri davranışlar, romanda Zeliha karakterine gösterilen ilgi bağlamında anlatılmaktadır. Hikmet Ali, Zeliha ile at gezintisini köylerden uzak yaptıklarını belirtmekte ve bunun nedenini de şöyle açıklamaktadır: "Köylere uğramadan keçi yollarından gidiyoruz. Zira Zeliha, çizmesinin ökçesini öpmek için koşuşacak olan kadınlarla çocukları rahatsız etmek istemiyor; belki de bu tapınma sahnesini benden esirgemek arzusundadır" (s. 109).

Sincar Dağı'nda at gezintisi anlatılırken yapılan şu tasvirin, en az çöl tasviri kadar güçlü ve etkileyici olduğu söylenebilir: "Bir aralık çok mu yükseldik yoksa hava mı fazla alçaldı, bulutlarla örtüldük. Gökte gibiyiz; atlarımızın ayakları buğudan köpüklere basıyor. 'Yezidilerin Olemp'inde Yezidi Minerv'iyle beraberim!' diye Zeliha'ya seslendim” (s. 109).

Daha önce Zeliha'nın ağzından, "Laik ve ciddi bir münevver" olarak tanımlanan Hikmet Ali'den Yezidilik inancının sırlarının gizlenmeyeceği belirtilmişti. Bu bölümde de Zeliha, Hikmet Ali'ye, "Size mukaddes emanetleri göstereceğim" dedikten sonra, bu emanetler ve onların bakımıla ilgilenen zümre hakkında şu bilgileri vermektedir: "Bunların tedarikinde epeyce zorluk çekildi. Muhafazası da teşrifata tabiidir. Muayyen bir sınıfa mensup olmayanlardan başkası hizmetinde bulunamaz. Mumlarını yakan, odayı silen, süpüren ve anahtarını saklayıp içerisine girmek, ziyaretçilere göstermek hakkı bu sınıfın imtiyazıdır. Bizde onlara Kuçek derler. Şimdi şatomuzda bu sınıftan dört kişi mevcut... Kendi dairelerinde otururlar, izzet, ikram görürler, aidat alırlar. Ayrıca rüya tabiri, gaybdan haber gibi ihtisasları vardır; Şeyh Aadi Türbesi'nin toprağıyla ilaçlar yaparlar, hastaları tedavi ederler. Hülasa her dinde gördüğümüz sınıflardan biri de odur" (s. 110).

$\mathrm{Bu}$ anlatımdan, kutsal ile temas kurmak anlamına da gelen kutsal emanetlere hizmet etmenin; belli bir sinıfa ait bir imtiyaz olduğunu öğreniyoruz. $\mathrm{Bu}$ sinifa mensup din adamlarının bazı ayrıcalıklar (kendi dairelerinde oturmak, izzet, ikram görmek ve aidat almak gibi) elde ettikleri ve onları diğerlerinden farklı kılan bazı görevlerinin (gaybdan haber vermek, ilaç yapmak ve hastaları tedavi etmek gibi) olduğu belirtilmektedir. Ancak, Kuçekler adı verilen bu sınıfın sahip olduğu imtiyazların kendilerinden kaynaklanmadığı, Kuçeklerin bu ayrıcalıkları, Yezidiler arasında en üst tabaka olan Yezidi emirlerine/mirlerine vekâlet ettikleri için elde ettikleri belirtilmektedir. Bu vekâlet görevi, Yezidi mirlerine yapılan eleștiriler ve bu eleștirilerin nedeni Zeliha'nın dilinden şöyle anlatılmaktadır: "Ziyaretinizi yabancı gözlerden uzak, rahat bir şekilde yapabilmeniz için Kuçeklere çekilmelerini emrettim ve anahtarı kendim aldım. Almak hakkımdır; zira bu gibi emanetlerin asıl muhafizları Yezidi emirleri, daha doğru tabirle mirleridir; Kuçekler bize vekâlet ederler. Şurası var ki mirlerimiz kendilerini, benim size anlattığım şekilde, Yezid'in sülalesinden hatta evkafının mütevellisi oldukları Şeyh Aadi'nin de ahfadından addetmezler; Emevi prensleri sanırlar" (s. 111). Burada yazar, Yezidi mirlerinin inançlarını öğrenmede ve anlatmada yeterli olmadıklarını ileri sürmektedir. Bu iddiasını, mirlerin arasından mezheplerinin (Yezidiliğin) tarihini ve felsefesini tetkik edecek derecede irfan sahibi adamlar henüz yetişmemiştir (s. 111) gerekçesiyle temellendirmektedir.

Romanda, Yezidi topluluğunun en üst tabakası olan mirlere yapılan eleştiriden sonra, bu toplulukta, mirler de dâhil yedi toplumsal tabakanın olduğu belirtilmektedir. Bu toplumsal tabakalar hiyerarşik sırasına göre şunlardır: "Mir, pesmir, pir, kuçek, kaval, mürit ve fikara" (s. 111). Tabakalaşma sisteminin en üst basamağında yer alan mirlerin, "hem ruhani, hem de cismani salahiyetlere haiz" olduğu; diğerlerinin ise sadece ruhani sıfatlarının olduğu belirtilmektedir. Ancak mirlerin, Yezidi topluluğu üzerindeki etkilerinin zayıfladığı ve bunun sonucunda tabakalar arasındaki geleneksel ilişki biçiminin "bozulduğu", toplumsal hayata "anarşinin" hâkim olduğu Zeliha'nın dilinden şöyle anlatılmaktadır: "İrfan ve servet azlığı, yazık ki son senelerde bütün cemaati karmakarışık etmiş, sınıflar birbirine girmiş, mirlerin nüfuzu kesilmiş, kuvvetimiz eksilmiştir. İrademi sarsan, şevkimi kıran işte bu anarşidir" (s. 111).

Yazar, Yezidi topluluğunun durumunun pek de iç açı1 olmamasının en önemli nedeni olarak Yezidi mirlerinin inançtaki güçlü konumlarının pratikteki yansımasının zayıf olmasını göstermektedir.

Kitapta, kutsalın insan düzeyindeki temsilcisi olan mirlerin toplumdaki konumlarının önemi ve eleştirisi yapıldıktan sonra, kutsalın maddi düzeydeki örneklerine geçilmektedir. Yazara göre, Yezidi topluluğunun madde düzeyindeki en önemli kutsalı bayraktır. Romanın Yezidi olmayan karakteri Hikmet Ali (anlatıc1, yazar), Yezidilerin kutsal emaneti olan Yezidi bayrağını ve bayrakla birlikte yer alan nesneleri şöyle tasvir etmektedir: "Bayrak direğinin ucuna altın olması lazım gelen bir madenden bir kuş heykeli kakılmıştı; hindi palazını andıran iri gözlü, kel kafalı, sıska bir kuş... Bu, şüphesiz acemi kuyumcu elinde Tavus'u temsil ediyordu. Bayrağın kumaşı sarı sırmayla işlenmiş ipektendi ve asıl garibi bu mukaddes remzin önüne bakırdan bir küçük beşik ve yine bakırdan bir havan eli konmuştu" (s. 112).

Kitapta, "mukaddes remz" olarak tanımlanan Yezidi bayrağının sarı sırmayla işlenmiş ipekten olması, bayrak direğinin ucunda, yazarın tasvir ettiği şekliyle bir kuş olması, bu kuşun Tavus'u temsil edip etmediği, şayet temsil ediyorsa bunun anlamı ve bayrağın önüne bakırdan bir beşik ile yine bakırdan bir havan eli konulmuş olması, bu nesnelerin her birinin Yezidilerde kutsal olduğunu, en azından kutsalın birer sembolleri olduklarını göstermektedir. Başka bir ifadeyle bunlar, Yezidi topluluğunun kültürel hazinelerinin işaretleridir. Bunların hem her birinin ayrı ayrı hem de birbirleriyle ilişkilerinin, konunun uzmanları tarafından tahlil ve tetkiklerinin yapılması, Yezidilerin yaşam biçimleri ve 
kültürel referansları hakkında önemli bilgilere ulaşılmasını sağlayacaktır.

Romanın bu bölümünde, Yezidilik uzmanı şarkiyatçı bir karakter karşımıza çıkar. Yazar bu bölümde, Yezidilik ve Yezidiler hakkında söylemek istediklerinin önemli bir kısmını bu şarkiyatçı karakterin ağzından söylemeyi tercih etmektedir. $\mathrm{Bu}$ yeni karakter, Yezidiler ve Yezidilik hakkındaki izlenimlerini, tespit ve çıkarımlarını şu cümlelerle anlatmaktadır:

Şarkiyatçı: "Bu küçük cemaatimiz çok ahlaklıdır. Ticaret yapmamak istemelerinin sebebi ticaretin yalana müsait olmasıdır. Yalan, üzerine Tavus'un gazabını celbeder. Aynı zamanda cesaretli ve kadınları hakkında fazla kıskançtırlar; bu yüzden epeyce cinayetler olur. Yezidi dini nedir? Bildiğimiz bütün itikatların bir salad rüs'üdür. Fakat temelini iki zıddı, yani iyilik ve fenalık mefhumlarını birbirleriyle uyuşturmak teşkil eder. Onun içindir ki her dine başvurmuşlar, hepsinden ümit ve şifa verici birer parça koparıp itikatlarına eklemişlerdir. $\mathrm{Bu}$ yamalardan ortaya çıkan şey, ilk bakışta biraz gülünç ve tenasüpsüzdür, çocukça cihetler vardır, reforma muhtaçtır. Lakin hangi din bu kusurlardan kurtulabilmiştir? Dinlere şiirini veren de o kusurlar değil mi? Yalanı insana şiddetle yasak eden itikatta ben yükseklik buluyorum. Bir Yezidi’ye hakikati söyletmek için etrafınıza elinizle, hayali bir daire çiziniz, bu Yezid'in halkasıdır, çıkmamak için Yezidi yalan söyleyemez" (s. 114).

Geleneksel toplumlar/topluluklar, inanç merkezli topluluklardır. $\mathrm{Bu}$ topluluklarda bireyin bireyle, bireyin kurumlarla ve yapıyla, bireyin doğayla ilişkisini inançları belirlemektedir. Başka bir ifadeyle inanç, hem bireyi hem de toplumu bütün yönleriyle kuşatmaktadır. Yezidi topluluğunun da bir inanç topluluğu örneği olduğu ve bu topluluğun her aşamasında inancın belirleyici ana faktör olduğu, hem kutsal emanetlerin anlatıldığı paragrafta hem de şarkiyatçının dilinden anlatılan Yezidilik ve Yezidilerle ilgili değerlendirmelerde ortaya konmaktadır.

Daha önce de belirtildiği gibi; yazara göre, Yezidilerin en önemli maddi kutsal emaneti Yezidi bayrağıdır. Bu kutsal emanet hakkında bilgi verildiği halde birkaç sayfa sonra tekrar bayrağa değinilmesinin nedeni, Yezidi topluluklarında bayrağın, bahar aylarında köy köy gezdirilmesi ve bu köylerde yaşayan insanların katıldığı bir törenle, bayrak örneğinde kutsala yaklaşma hatta bazılarının temas kurma imkânını sağlayan dini bir törenin öznesi olmasıdır. Bundan dolayı Hikmet Ali (anlatıcı, yazar), şarkiyatçıya "Mukaddes bayrakları hakkında ne biliyorsunuz?" (s. 114) sorusunu sorar.

Şarkiyatçı, Yezidi bayrağının öznesi olduğu töreni şöyle anlatmaktadır: "Bayrak en eski zamanlardan beri milletlerde ve cemaatlerde toplaşma ve bir maksat için birleşme alameti olarak kullanılmıştır ve bundan dolayı da gittikçe bir kutluluk almıştır. Yezidi bayrağının da bu itibarla herhangi bir bayraktan fazla manası yok. Yezidi şeyhleri, bahar gelince köy köy bir bayrak getirirler, bu, güya Yezid'in mukaddes bayrağıdır. Heyetin önünde ilahiler okuyan ve davullar çalan adamlar, ayrıca münadiler vardır. Bir köye yaklaşıldı mı, atlılardan biri daha önce koşar, 'Sancak-1 şerif geliyor!' diye her bir tarafa bağırır, müjde verir. Halk en yeni, en güzel elbiselerini giyer, karşıcı çıkar. Erkekler davulların arkasına dizilirler ve hep birden ilahiler okumaya başlarlar; kadınlar, ellerinde buhurdanlarla ve keskin yaygaralar kopararak şenliğe karışırlar. Bir aralık şeyh haykırır:
'İçinizde sancağı evinde misafir edecek kimdir?'

Köylülerden biri atılır:

'Yüz kuruşa benim misafirimdir!'

'İki yüze benim!'

Bu bir müzayededir. Nihayet birinin üzerine kalır; heybe atın sırtından indirilir ve müzayedeyi kazananın boynuna geçirilir. Lakin Sincar'dan Halep vilayetindeki Kürtdağı'na kadar götürülen bu bayrak, pek ehemmiyetle bir yerde saklandığını işittiğim asıl ve kutsi bayrak olmasa gerektir. Prenses, herhalde bu meseleler hakkında ekselansınızı benden daha salahiyetle aydınlatabilir" (s. 115).

Bu bölümün ve dolayısıyla kitabın sonuna doğru yaklaşıldıkça Yezidilerin Tanrı anlayışına tekrar değinilmekte; Yezidi inancında, Tavus Melek ile Yezdan'ın özellikleri ve aralarındaki fark verilmektedir. Yazar, önce, Tavus Melek'le ilgili şu tespitlerde bulunmaktadır: "Anladım ki Tavus Melek dedikleri ilah bizim şeytanımızdan başkası değildir. Bizim şeytanımız ve eski İran dininin Ehrimen'i... Fakat aralarında şu fark var: Yezidi Ehrimen'i hem iyilik, hem de fenalık yapabilir: İyiliği sağ elinde, fenalığı sol elinde tutar ve bunları istediğinde, dilediği gibi dağıtır. Şerrinden korunmak için bu tehlikeli mabuda yaranmak lazımdır" (s. 120). Yazarın, "şeytanımız" dediği Tavus Melek'in Yezidi inancındaki konumu ve bu bağlamdaki inançlar, Yezidiliğin en özgün yönlerinden biridir. Yezidi olmayanların Yezidileri "şeytana tapanlar" olarak tanıdıkları hatırlandığında, bu konunun özgünlüğü ve önemi daha iyi anlaşılacaktır. Hatta Yezidiliğin Tavus Melek merkezli bir inanç sistemi olduğu; Yezidi inancı müminlerinin, hem doğa hem de "öteki”" ile ilişkilerini Tavus Melek inancına göre belirledikleri ileri sürülmektedir. "Yezidiler, kendi dinlerinden olmayanların bile şeytana saygı göstermesini isterler. Dillerinde şeytan telaffuzunu andıran ne varsa onunla başları hoş değildir: Maruldan, lahanadan, domuz etinden bu sebeple kaçarlar. Yere tükürmezler. Belki Tavus o sırada yerdedir. Mavi renkli kumaş giymezler; zira beyaz maviye boyanabilir, lakin mavi tekrar beyaz olamaz. Bunun manası şudur: Yabancı dinden bir adam, Yezidi imanıyla doğmamışsa mavi sayılır; o bir daha beyaz olamaz; hâlbuki Yezidi aslında aktır, dinini değiştirmiş de olsa, yani mavileşse de yine Yezidi itibar olunur" (s. 120 - 121).

Yazarın Yezda ile ilgili görüşleri ise şöyledir: “Asıl büyük Yaradan'a gelince, ondan çekinmeye lûzum yoktur; zira o, Yezdan, yalnız iyidir, iyiliğin zübdesi (öz), lübbül lübbüdür (özün özü); kemal, cemal sahibidir; intikamcı ve ceza verici değildir. Bütün fenalıkların kaynağı olan Tavus ne kadar şer varsa üzerine almıştır. İşte bundan dolayıdır ki Yezidi, şeytandan ürker, ürktüğü için de onun hoşuna gitmeye çabalar, çabalamanın şeklini tapmak derecesine vardırır" (s. 120).

Romanda, Yezidilerin Müslümanlara ve Hristiyanlara bakışına da yer verilmekte ve Yezidilerin Hristiyanlara bakışı şöyle değerlendirilmektedir: 'Zeliha'nın Katolikliği işte bu ustalıklı akideden dolayı bir suç sayılmıyordu. Zaten Yezidi Hristiyan'a fazla bir yakınlık duyar; içlerinde kiliselere giren ve girerken eşiğini öpenler çoktur. Hatta kadınları Hristiyan'dan örtünmez, evine misafir eder, kızları hizmetine koşar. Bütün bunlar, bence o cemaatin Hristiyan'dan, komşu olmadığı cihetle zarar görmemiş olmasındandır. İsa'nın erenlerine, kendi azizleri derecesinde hürmet göstermeleri de bundandir" (s. 121). 
Kitapta Yezidilerin İslam'a bakıșı ve İslam ile ilișkisi hakkında ise şu değerlendirmelere yer verilmektedir: "TürkIrak hududu hakkında tahkikat yapmaya gitmiş olan Akvam Cemiyeti Heyeti, raporunda Yezidilerin Muhammedi olmadıkları kanaatini vermiştir. Fakat salahiyetli ilim adamlarından teşekkül etmeyen bu heyet, aynı zamanda Muhammedilerle beraber Müslüman peygamberini tanıdıklarını ve Kur'an'dan ayetler seçip mabet duvarlarına yazdıklarını zikretmektedir. Yezidilik şüphesiz İslamiyet çerçevesine giren yüzlerce şubelerden biri, yine şüphesiz bunların en acayibidir" (s. 121). "Mukaddes kitapları, Kur'an'dan alınmış bazı surelerden toplanmıştır; fakat bu surelerdeki şeytan ve recim kelimeleri silinmiştir. Büyük fakihten başka kimse bu kitaba el süremez ve bir cümlesini okuyamaz. Yezidi kıyamet gününe, Araf'a, Mehdi'ye, sonsuz hayata inanır. Bunlara bakınca mösyö Rondel'in Rus salatası tabirini pek doğru bulmak icap eder" (s. 121).

Yezidilerin hac töreni ile Yezidilere atılan mum söndü iftirası arasında ilişki kurulmakta ve bu konularda şu tespitler sunulmaktadır: "Sabahleyin güneşe karşı eğilip içinden birkaç kelime mırıldanmak... İşte namazları. Kanun ayında üç gün oruç, eylülde hac seferi... Bütün din külfeti bu! Mösyö Rondel'e göre hac için Mekke'ye değil, Musul'la İmadiye'ye Rondel'e Şeyh Aadi'nin türbesine giderler; zengin evkafi olan bu türbenin mütevellileri Yezidi emirlerinden seçilir" (s. 122). "Haksız ve asılsız olarak Yezidilere nispet edilen mum söndü isnadı, bu hac seferiyle ilişkilidir. Mum söndü ayini Şabak adı verilen büsbütün ayrı bir cemaatin çirkin bir âdetidir" (s. 122).

Yezidin Kızı romanında, Yezidi topluluklarının düğün ve cenaze törenleriyle ilgili ilginç bilgilere de yer verilmektedir. Kitapta, Yezidi düğünleri hakkında şu bilgilere rastlanır: "Yezidilerde düğünler uzun sürüyor; kendilerine göre hususiyetleri de vardır. Mesela evlenme kararlaştı mı köylüler davul zurna önde, güvey evine gidiyorlar; orada üç gün üç gece kadın erkek yiyorlar, içiyorlar, oynuyorlar; sonra atlar geliyor, kadınlar bunlara ikișer ikișer biniyorlar, erkekler teker teker... Alay, gelinin kapısına dayanıyor ve havaya silahlar sıkılıyor. O zaman kız babası dışarıya çıkıp soruyor:

'Ne istiyorsunuz?'

'Kızını!' diyorlar.

Baba içeriye giriyor, gelini kırmızı renkte bir kumaşla örtüyor. Çeyiz sandıklara konmuştur. Gelenler eve doluyor; meydanda bir sürü tahta kaşık vardır; köy çocukları bunlardan birer tanesini başlarına sokuyorlar; hep birden, kızı alıp güveyin evine götürüyorlar. Üç gün üç gece, yine çalgılı, dans, şenlik.

Üçüncü günün akşamı şeyh, güveyi gelinin odasına sokuyor, ellerini birbirinin eline veriyor; ikisinin başından bir örtü geçiriyor ve soruyor:

\section{'Kimsin? Kimin oğlusun ve kızısın?'}

İki taraf bunların cevabını veriyor. O zaman şeyh kırmızı bir boya ile gelinin ve güveyin omuzlarına, alınlarına birer nişan koyuyor; sonra bir dal uzatıyor:

'Uçlarından tutunuz ve kırınız.' diyor. 'Siz de ecel ayrılıncaya kadar birbirinize bağlı kalacaksınız, nitekim bu dal da kuvvet kendisini ortadan ikiye bölünceye kadar bir parçaydı!'

Bu dal kırmak remzi de gösterir ki Yezidilerde boşanma âdeti yok gibidir; çok ağır, ciddi sebepler olmazsa nikâh bozulamaz" (s. 127).
"Şeyh demin anlattığım merasimi yerine getirdikten sonra odadan çıkar, çiftler yalnız kalırlar. Kapının dışında şeyh, güveyin duvara birkaç yumruk atmasını beklemektedir; bunu işitince havaya bir el silah boşaltır. Silah sesi zifaf işaretidir; biriken halk dağılır ve asıl güzeli, yeni evliler tam yedi gün, evlerinde baş başa kapalı kalırlar. Bu, kimsenin rahatlarını bozmak istemediği bir balayı haftasıdır" (s. 128).

Romanda, Yezidilerin cenaze törenleriyle ilgili olarak şu bilgilere yer verilmektedir: "Cenaze törenleri de uzun sürmektedir; onun şekilleri de eski milletlerin adetlerini hatırlatmaktadır. Mesela mevkice yüksek biri öldü mü, akrabası insan biçiminde, tahtadan bir kalıp hazırlar, buna cenazenin elbiselerini giydirirler. Başında ağlanan matem tutulan, mersiyeler okunan bu tahta parçasıdır. Üç gün halk onu ziyarete gelir; fakat gelenler, güya vakadan habersizdirler. Sorarlar:

'Neniz var? Ne oluyorsunuz?'

Ölü tarafı şu cevabı verir:

'Oğlumuzu evlendiriyoruz, bu hazırlık onun yeni düğününün hazırlığıdır!'

Üçüncü günü ölü, Müslümanlardaki gibi yıkanır, Yahudilerdeki gibi de kulakları, burun delikleri pamukla tıkanır. Şeyh dua okur ve sonra şeyh Aadi'nin türbesinden getirilmiş toprağı suyla yoğurup cenazenin alnına, gözlerine, koltuk altlarına ve yüreğinin üzerine sürer; gömüldüğü zaman da şu hitapta bulunur: 'Ey insanoğlu! Topraktan gelmiştin, bugün toprağa dönüyorsun!'

'Ey insanoğlu topraktan gelmiștin, bugün toprağa dönüyorsun!'

Fakat ölen adam kara cüppelilerden, yani şeyh mertebesindeyse, matem yasaktır; türküler çığrılarak şenlikler yapılır, gömülme işinden sonra da kurbanlar kesilip dağıtılır. Zira şeyhin ruhu doğruca, hiçbir iskeleye uğramadan, cennete gidecektir. Buna keder edilemez, sevinmelidir!" (s. 128-129).

Yezidin Klzı romanında, Yezidi topluluğu ve inançlarıyla ilgili olarak verilen bilgiler düğün ve cenaze törenleri anlatımlarıyla sona ermektedir. Düğün töreninde zümreler arasında bir farklılığın olduğu hakkında bilgi verilmezken sıradan bir Yezidi'nin ölümü ile inanç açısından üst mertebede olan bir Yezidi'nin ölümlerini değerlendirmede ve yapılan törende farklılık olduğu belirtilmektedir. İkisi arasındaki bu fark, "matem tutmak" ile "sevinç duymak" arasındaki fark kadar büyük olduğu için dikkat çekici ve ilginçtir.

Cenaze törenlerinde dikkat çeken noktalardan biri de ölüm töreni için, "Oğlumuzu evlendiriyoruz, bu hazırlık onun yeni düğününün hazırlığıdır!” denerek düğün ile ölüm arasında benzerlik kurulmasıdır. Bir diğer nokta ise, "Ey insanoğlu topraktan gelmiştin, bugün toprağa dönüyorsun!” ifadesinin iki kez tekrarlanmasıdır. Bu ifadeyle insanın topraktan geldiği ve öldüğünde yine toprağa yani aslına döndüğü vurgulanıyor.

\section{Sonuç}

Refik Halit Karay, eserlerinde seçkin ve şehirli olandan ziyade halk kültürüne yer veren İstanbullu bir gazeteci ve yazardır. İki kez sürgün hayatı yaşamıştır. İlkini Anadolu'da, ikincisini ise Suriye'de geçirmiştir. Türk, Müslüman, Sünni ve İstanbul yaşam tarzını benimsemiş bir yazar olarak Suriye'de kaldığı on beş yıl gibi uzun bir süre içinde, Yezidilik inancını ve bu 
inançla şekillenmiş Yezidi topluluğunu tanıma imkânını bulmuştur. $\mathrm{Bu}$ sürgün dönemindeki bazı tecrübelerini, Yezidilik ve Yezidiler hakkında öğrendiklerini ustaca kurguladığı Yezidin Kızı romanında anlatmıştır. Makalede, romandaki sırasına göre yer verilen bu bilgilerin, aynı dönemde farklı kaynaklarda yer alan başka tespitlerle birlikte ele alınması durumunda, Yezidilik ve Yezidilerle ilgili literatüre katkı sunacağı öngörülmektedir.

Karay’ın, Yezidin Kızı romanında yer verdiği bilgiler yalnızca onun gözlem, görüşme ve tecrübelerinden oluşmamaktadır. Yazarın bunlarla birlikte, döneminde var olan ilgili literatürden de haberdar olduğu ve hazırlanan bazı raporları incelediği anlaşılmaktadır. Romanda, Yezidi topluluğunun tarihi, coğrafyası, nüfusu, inancı, bu inancın özellikleri ve diğer inançlarla ilişkisi, benzerlikleri ve farklılıkları; toplumdaki sosyal tabakalar ve bu tabakaların ilişsi biçimleri, bazı tabakaların imtiyazları, halkın yaşam biçimi ve standartlar1; efsaneleri, hikâyeleri, söylenceleri ve törenleri hakkında geniş bir bilgi sunulmaktadır.

Yazar, Yezidilik inancının eklektik bir inanç sistemi olduğunu, "Bildiğimiz bütün itikatların bir salad rüs'üdür", "Her dine başvurmuşlar, hepsinden ümit ve şifa verici birer parça koparıp itikatlarına eklemişlerdir" ifadeleriyle dile getirdikten sonra, bu inanç sistemi hakkında "Temelini iki zıddı, yani iyilik ve fenalık mefhumlarını birbirleriyle uyuşturmak teșkil eder" tespitinde bulunmaktadır. Yazar bu tespitlerinden hareketle: "Onun içindir ki bu yamalardan ortaya çıkan şey, ilk bakışta biraz gülünç ve tenasüpsüzdür, çocukça cihetler vardır, reforma muhtaçtır." yargılarında bulunuyor ve akabinde "Lakin hangi din bu kusurlardan kurtulabilmiştir? Dinlere şiirini veren de o kusurlar değil mi?" diyerek bu yargıların bütün dinler için geçerli olduğunu ileri sürmektedir. Ayrıca, "Yalanı insana şiddetle yasak eden itikatta ben yükseklik buluyorum." ifadesiyle de Yezidilik inancının en beğendiği yönünü vurgulamaktadır.

Romanda yer alan bilgilerden, Yezidilikteki teslis inancinda tanrıların eşit olmadığı, bireysel ve toplumsal hayatın her alanının inançla şekillendiği geleneksel Yezidi topluluklarında yine inançla belirlenmiş farklı toplumsal tabakaların olduğu sonucuna ulaşılmaktadır.

Yezidin Klzl, hâlâ okunan bir roman olduğuna göre, bu romanda yer alan Yezidiler ve Yezidilik hakkındaki bilgi, tespit ve çıkarımların; başta sosyolog, antropolog ve ilahiyatçılar olmak üzere sosyal bilimciler tarafından farklı boyutlarıyla tahlil ve tetkik edilmesi gerekmektedir. Yazarın, Yezidiliğin ne olduğu konusunda bir karara varamadığ anlaşılmaktadır. Yezidilik, kitabın bir yerinde din olarak tanımlanırken; başka bir yerinde mezhep olarak tanımlanmaktadır. Yine yazar, Yezidilere atılan mum söndü iftirasını reddederken aynı ithamı, kendisi de başka bir inanç topluluğu olan Şabaklar için tekrarlamaktadır.

Refik Halit Karay'ın Yezidin Kızı Romanında Yezidilik, Yezidiler ve Bazı Tespitler ismiyle yazılan bu makalenin, konuyla ilgili literatüre katkı sunabilecek çalışmalara öncülük etmesi temenni edilmektedir. Bu temenninin gerçekleşmesi makalenin yazarı için büyük bir bahtiyarlık olacaktır.

\section{Kaynakça}

Ahmedzade, H. (2004), Ulus ve Roman, Azad Zana Gündoğan (Çev.), İstanbul: Pêrî Yayınları.

Aktaş, Ş. (2014), Refik Halit Karay, Ankara: Türk Dil Kurumu Yayınları.

Baran, A. G. (2013), Genç ve Gençlik: Sosyolojik Bir Bakış, Gençlik Araştırmaları Dergisi, 1(1), 6-25.

Baydar, M. (1960), Edebiyatçılarımız Ne Diyor, İstanbul: Ahmet Halit Yaşaroğlu Kitapçılık.

Bayraktar, M. (2012), "Yezidin K1z1 ve Ezidiler", (Erişim:18.05.2018),http://politikart1.blogspot.com.tr/ 2012/02/yezidin-kz-ve-ezidiler-mehmetbayrak.html?q=bayraktar.

Ebcioğlu, H. M. (1943), Kendi Yazıları ile Refik Halit, İstanbul: Semih Lütfi Yayınları.

Eriksen, T. H. (2009), Küçük Yerler Derin Mevzular, Fahriye Adsay (Çev.), İstanbul: Avesta Yayınları.

Göle, Nilüfer (2013), "Yer Sofrası ve Sınır İhlalleri", (Erişim:18.05.2018),http://t24.com.tr/yazarlar/bilinme yen/yer-sofrasi-ve-sinir-ihlalleri,7056.

Giddens, A. ve Sutton, W. P. Sosyolojide Temel Kavramlar, Ali Esin (Çev.), Ankara: Phonix Yayınları.

Kabaklı, A. (1966), Türk Edebiyatı, Cilt 3, İstanbul: Türkiye Yayınevi.

Kaplan, M. (1985), Şiir Tahlilleri, İstanbul: Dergâh Yayınları.

Kaplan, M. (1997), Hikâye Tahlilleri, İstanbul: Dergâh Yayınları.

Karabulut, D. (2018), "Yerinden Edilmenin Söylemsel Şiddete Dönüşümü: Refik Halid Karay ve Sürgünlük Deneyimi”, Monograf Edebiyat Eleştirisi Dergisi 2018/9: (46-74).

Kudret, C. (1965), Türk Edebiyatında Hikâye ve Roman, İstanbul: Varlık Yayınları.

Öksüz, M. (2017), "Sürgünlügün Yazar Üzerindeki Etkileri: Refik Halit Karay Örneği”, Tilbe, A. Vd. (Yay. Haz.), Göç Konferansları Seçilmiş Bildiriler Kitabı içinde (ss. 275-284). Londra: Transnational Press.

Yücel, H. A. (1957 ), Edebiyat Tarihimizden, Ankara: Türk Tarih Kurumu Yayınları. 